\title{
Composition and Characteristics of Cell Walls of Smooth Strains of Salmonella typhimurium and Derived Rough Variants
}

\author{
By M. HERZBERG AND J. H. GREEN \\ Department of Bacteriology, University of Florida, Gainesville, Florida, U.S.A.
}

(Received 6 December 1963)

\begin{abstract}
SUMMARY
Cell walls of two smooth strains of Salmonella typhimurium and their derived rough variants were found to be very similar in composition as determined by analyses for nitrogen, phosphorus, hexosamine and lipid. The rough cell walls contained less reducing substance than their parent smooth forms, $3.8 \%$ against $15.6 \%$ and $4.2 \%$ against $10.7 \%(\mathrm{w} / \mathrm{w})$. The sugar components common to rough and smooth cell walls were glucose, hexosamine, heptose and a 2-keto-3 deoxy sugar. In addition smooth cell walls possessed rhamnose, abequose and a larger content of mannose and glucose. Treatment with sodium lauryl sulphate produced a greater decrease in the extinction of suspensions of smooth walls than of rough cell walls. Rough cell walls were more susceptible than smooth to lysis by an ethylenediamine tetra-acetate (EDTA) + lysozyme system.
\end{abstract}

\section{INTRODUCTION}

Antigenic variation or 'dissociation' of smooth cultures to rough variants is an ever present problem in dealing with cultures of Enterobacteriaceae. Frequent emergence of rough variants appears to be due to selective forces operating in the media and the cultural conditions used for the cultivation and maintenance of cultures of these organisms in the laboratory. Endotoxic potency and somatic antigen reside in the lipopolysaccharide complex of the cell wall (Carey \& Baron, 1959) and changes in this substance are reflected in such parameters as antigenic specificity (Edwards \& Ewing, 1962), virulence, mode of growth; all apparently correlated with surface characteristics (White, 1929) and susceptibility to the bactericidal effect of antibody and complement (Wardlaw, 1963). The chemical composition of extracted lipopolysaccharides of smooth and rough bacteria has been studied intensively by Westphal and his collaborators (Kaufmann, Kruger, Lüderitz \& Westphal, 1961; Lüderitz, Kaufmann, Stierlin \& Westphal, 1960; Kröger, Lüderitz \& Westphal, 1959), and their immunological specificity in regard to sugar composition by Staub and her collaborators (Staub, Tinelli, Lüderitz \& Westphal, 1959). These studies have shown differences in composition of lipopolysaccharide which were striking and consistent among the various species of the genus Salmonella, showing the correlation between serological specificity and chemical composition. The composition of the lipopolysaccharide of rough organisms indicated that they differed from smooth strains by virtue of the absence of certain components. Most studies except those of Wardlaw (1963) have involved 
extracted lipopolysaccharide rather than the entire cell wall. The extracted lipopolysaccharide represents only that portion of the cell wall which is removed by the procedure employed. Since there may also be changes in components other than lipopolysaccharide, the present studies were made to compare the total composition of the entire walls of smooth and rough strains.

\section{METHODS}

Cell wall preparation. The method of Salton \& Horne (1951) was used, with minor modifications, utilizing washed $(\times 3)$ 18-24 $\mathrm{hr}$ cultures grown on brain-heart infusion agar (Difco), which were disrupted in a Mickle tissue disintegrator with ballotini beads, with subsequent repeated washing and differential centrifugations. To rid the walls of cytoplasmic components treatment with trypsin was used (4.0 mg. Difco 1/300 trypsin added $/ \mathrm{ml}$. packed cell wall) in phosphate buffer $(\mathrm{pH} \mathrm{7 \cdot 0,} \mathrm{M} / 15)$ at $37^{\circ}$ for $2 \mathrm{hr}$ with gentle shaking. Previous experiments had shown that deoxyribonuclease or ribonuclease treatment did not increase to purity. Subsequent repeated centrifugations at low and high speeds yielded cell walls free from cytoplasmic components. The preparations were kept at $-20^{\circ}$ and thawed before use.

Electron microscopy. Purity was determined visually by the appearance of photomicrographs of chromium-shadowed preparations made with a Phillips EM-100 electron microscope. Lack of visible intracellular material was the chief index of purity (see Fig. 5).

Analytical methods. All analyses, which were repeated at least once, were related to weight of cell wall dried to constant weight in vacuum oven at $80^{\circ}$. Nitrogen was determined by the micro-Kjeldahl method described by Harrow et al. (1955). Total phosphorus in $6 \mathrm{~N}-\mathrm{H}_{2} \mathrm{SO}_{4}$ digests was analysed by the colorimetric method of Fiske \& SubbaRow (1925). Reducing substances of $2 \mathrm{~N}-\mathrm{HCl}\left(100^{\circ}\right)$ hydrolysates prepared by the method of Salton (1953) were determined by the anthrone method of Scott \& Melvin (see Kabat \& Mayer, 1961), and hexosamine of the same hydrolysates by the Elson-Morgan reaction (Kabat \& Mayer, 1961). Rhamnose and aldoheptose were determined by the cysteine + sulphuric acid method of Dische (1955) and mannose also by the cysteine + sulphuric method of Dische \& Shettles (1948). The 2-keto-3-deoxyaldonic acids ('sialic acid') were assayed by the thiobarbituric acid method of Warren (1959), on $0 \cdot 1 \mathrm{~N}-\mathrm{H}_{2} \mathrm{SO}_{4}\left(80^{\circ}\right)$ hydrolysates, and abequose in the same hydrolysates was measured at $534 \mathrm{~m} \mu$ (see Results). DNA was assayed by the diphenylamine method of Burton (1956) in $0.5 \mathrm{~N}$ cold and hot perchloric acid extracts. Lipid analysis was by the method of Salton (1953), involving hydrolysis of the cell walls in $6 \mathrm{~N}-\mathrm{H}_{2} \mathrm{SO}_{4}$ at $100^{\circ}$, extraction of the hydrolysate with diethylether and gravimetric analysis of solids in the extract. Chromatography of carbohydrates was done on $2 \mathrm{~N}-\mathrm{H}_{2} \mathrm{SO}_{4}$ hydrolysates prepared by the method of Salton (1953), neutralized, and sulphate removed with solid $\mathrm{Ba}(\mathrm{OH})_{2}$ and after filtration dried over solid $\mathrm{NaOH}$ and concentrated $\mathrm{H}_{2} \mathrm{SO}_{4}$. The final product was redissolved in distilled water and chromatographed on Whatman No. 1 paper with $n$-butanol + pyridine + water $(\mathbf{4 5}+\mathbf{2 5}+\mathbf{4 0}$ by vol.) as solvent. The chromatograms were developed by spraying with aniline phthalate reagent and heating at $105^{\circ}$ for $5 \mathrm{~min}$. (Partridge, 1949). Sugars were identified by comparison of $\boldsymbol{R}_{F}$ with known sugars, 
except for heptose and 2-keto-aldobionic acids ("sialic acid'). Chromatograms developed in $n$-butanol + acetic acid + water $(4+1+5$ by vol.) were examined for hexosamine with a modified Elson-Morgan reagent (Partridge \& Westall, 1948). Hydrolysates for amino acids were prepared in $6 \mathrm{~N}-\mathrm{HCl}$ in sealed tubes for $26 \mathrm{hr}$ at $121^{\circ}$. They were then decolorized with charcoal and dried over concentrated $\mathrm{H}_{2} \mathrm{SO}_{4}$ and solid $\mathrm{NaOH}$, and were reconstituted in distilled water.

Virulence and toxicity. These were determined as described in a previous publication (Herzberg, 1962).

Strains of Salmonella typhimurium. Strain 7 was a smooth virulent strain previously described and strain CL 11 was a rough variant derived from it (Herzberg, 1962). Strain 6, a smooth isolate from strain SR 11, and strain 4, its rough variant, were kindly given by Dr Ellen Simon (University of Wisconsin). The characteristics of these strains appear in Table 1.

Table 1. Characteristics of strains of Salmonella typhimurium studied

\begin{tabular}{|c|c|c|c|c|c|}
\hline & Characteristics & $7(\mathrm{~S}) *$ & CL11 (R) & $6(\mathrm{~S})$ & $4(\mathrm{R})$ \\
\hline (1) & Virulence & $\mathbf{0} / \mathbf{1 0}$ & $10 / 10$ & $0 / 10$ & $10 / 10$ \\
\hline (2) & $\begin{array}{l}\text { Toxicity of whole cells } \\
\text { (LD50, mg.) }\end{array}$ & $2 \cdot 8$ & $>4.0$ & $1 \cdot 7$ & $\mathbf{9} \cdot \mathbf{0}$ \\
\hline & Toxicity of cell walls & $0 \cdot 7$ & nt & nt & $1 \cdot 8$ \\
\hline (3) & Specific agglutination & + & $(-)$ & + & $(-)$ \\
\hline (4) & Acriflavine agglutination & - & + & - & + \\
\hline (5) & Saline agglutination & - & + & - & + \\
\hline (6) & Growth in broth & $\mathbf{T}$ & Sed & $\mathbf{T}$ & Sed \\
\hline (7) & Colony form & $\mathbf{S}$ & $\mathbf{R}$ & $\mathbf{S}$ & $\mathbf{R}$ \\
\hline
\end{tabular}

(1) Virulence: survivors/total, of albino mice 3 weeks after intravenous inoculation of $5 \times 10^{4}$ bacteria.

(2) Toxicity: LD50 expressed as mg. dry wt. heat-killed bacteria or cell walls, inoculated intraperitoneally to kill $50 \%$ of albino mice within $\mathbf{7 2} \mathrm{hr}$ as determined by the method of Goldberg, Watkins, Dolmatz \& Schlamm (1954). nt, not tested.

(3) Specific agglutination: utilizing somatic group B Salmonella (Capell) antiserum. (-) rough organisms also agglutinate non-specifically in saline and antisera of the other Salmonella serological groups.

(4) Acriflavine agglutination with $1 / 1000(w / v)$ neutral acriflavine.

(5) Saline agglutination with $0.9 \%$ saline.

(6) Growth in broth: T, evenly dispersed turbidity; Sed, heavy sediment in brain heart-infusion broth.

(7) Colony form: S, smooth, moist, even edge; R, rough, undulant edge on trypticase-soy agar.

* (S), Smooth; (R), rough.

Spectrophotometry. Absorption spectra and spectrophotometric analyses were determined on the Spectronic-505 recording spectrophotometer. Extinction was measured at $600 \mathrm{~m} \mu$ on the Spectronic-20 spectrophotometer. (Both instruments products of Bausch and Lomb Optical Co., Rochester, N.Y.)

Media. The media used were brain-heart infusion broth (Difco), Trypticase soy broth (BBL), lactate and glycerol defined media of Fraser \& Jerrel (1953) and Trypticase sea-water broth consisting of Trypticase broth to which has been added a mixture of salts to mimic sea water (Pratt \& Happold, 1960). 
Density determinations. Sucrose gradients were prepared by overlaying, in $2 \mathrm{ml}$. amounts, concentrations of sucrose of $50,40,30,20,10$ and $5 \%(w / v)$ in plastic tubes of $15 \mathrm{~mm}$. diameter, the gradient being allowed to form overnight at $4^{\circ}$. The gradients were overlayed with $0.5 \mathrm{ml}$. of the preparation of cell wall or whole bacteria in water and centrifuged in the cold $\left(5^{\circ}\right)$ in an International PR-2 centrifuge at $3000 \mathrm{rev} . / \mathrm{min}$., in a bucket rotor, at about $2400 \mathrm{~g}$.

Lysis of cell walls. The effect of lysozyme and ethylenediaminetetra-acetic acid (EDTA) was determined by measuring extinction changes at $600 \mathrm{~m} \mu$ in $0.2 \mathrm{M}$-tris buffer (Sigma Chemical Co.) pH $8 \cdot 0$, with EDTA $0 \cdot 32 \mathrm{mg} . / \mathrm{ml}$., and lysozyme (Difco; egg white lysozyme) $10 \mu \mathrm{g} . / \mathrm{ml}$., in a total reaction volume of $5 \mathrm{ml}$. according to the method of Repaske (1956). The effect of sodium lauryl sulphate was studied in $\mathrm{M} / 15$ phosphate buffer ( $\mathrm{pH} 7 \cdot 0$ ) by the method of Shafa \& Salton (1960).

\section{RESULTS}

\section{Purity of preparations}

The cell walls, as obtained by the method described, were free from cytoplasmic components, when shadowed preparations were observed by electron microscopy (Pl. 1, fig. 1, 2, 3, 4). The disc-like structures present inside as well as outside the cell walls are probably rounded-up cell membranes. No preparation was free from this material which did not, however, resemble the dense cytoplasmic components seen in unbroken cells (Pl. 1, fig. 5). Differences between smooth and rough cell walls were not apparent in these preparations. Deoxyribonucleic acid was absent as determined on perchloric acid extracts by Burton's method. The specific gravity of either rough or smooth walls was essentially the same as determined in sucrose gradient. Cell walls were of a lower density than whole cell preparations since they did not sediment at $2400 \mathrm{~g}$. for $2 \mathrm{hr}$ past a level of about $36 \%$ sucrose while whole cells sedimented to the bottom of the tube ( $50 \%$ sucrose). The pure cell walls sedimented in a band distinct and separate from the whole bacteria and they could be separated from admixture with whole bacteria by this method. Thus the cell wall preparations were essentially free from whole bacteria by this criterion also. The toxicity, determined as the LD50 dose on a weight basis, of the cell walls was approximately four to five times greater (i.e. LD50 values were four to five times smaller) than that of the whole bacteria (Table 1), indicating that such toxicity resides in the cell walls and that Salton's estimate of the cell wall being approximately $20 \%$ of the weight of the whole cell is quite reasonable (Salton, 1960). This ratio of toxicity of cell walls to that of whole bacteria was consistent in experiments involving other strains as well (Herzberg, Green \& Boring, 1960).

\section{Composition of cell walls}

Cell walls derived from smooth or rough strains were remarkably similar in composition as reflected in nitrogen, phosphorus, hexosamine and lipid determinations (Table 2). These values are comparable with those reported by Salton (1960) from cell walls of Escherichia coli. The figures for lipid content, while not well reproducible between analyses, did not indicate any significant or consistent difference between the two kinds of walls; the results are in the range found for other enteric organisms (Salton, 1960). The only significant and consistent difference 
was in the reducing sugar values, where rough cell walls were invariably the poorer in total reducing substance (expressed as glucose). The cell walls of the two rough strains possessed only $40 \%$ (strain 4 ) and $24 \%$ (strain CL 11) of the reducing substance found in their parent smooth cell walls.

Table 2. Cell wall composition of smooth and rough strains of Salmonella typhimurium

\begin{tabular}{|c|c|c|c|c|c|}
\hline Strain & $\begin{array}{c}\text { Total } \\
\mathbf{N}\end{array}$ & $\begin{array}{c}\text { Total } \\
\mathbf{P}\end{array}$ & $\begin{array}{l}\text { Reducing } \\
\text { substance } \\
\text { (expressed } \\
\text { as glucose) }\end{array}$ & $\begin{array}{c}\text { Hexosamine } \\
\text { (expressed } \\
\text { as } \\
\text { glucosamine) }\end{array}$ & Lipid \\
\hline & \multicolumn{5}{|c|}{$\%$ Composition $(w / w)^{*}$} \\
\hline$\gamma(\mathrm{S})$ & $10 \cdot 4$ & $1 \cdot 5$ & $15 \cdot 6$ & $4 \cdot 1$ & $14 \cdot 2,18 \cdot 4$ \\
\hline CL $11(R)$ & $9 \cdot 0$ & $2 \cdot 5$ & $3 \cdot 8$ & $3 \cdot 5$ & $21 \cdot 5,23 \cdot 7$ \\
\hline $6(\mathrm{~S})$ & $9 \cdot 8$ & $1 \cdot 7$ & $10 \cdot 7$ & $3 \cdot 8$ & $18 \cdot 4,20 \cdot 2$ \\
\hline \multirow[t]{2}{*}{$4(\mathrm{R})$} & $9 \cdot 9$ & $1 \cdot 1$ & $4 \cdot 2$ & $\mathbf{3 \cdot 5}$ & $14 \cdot 4,20 \cdot 2$ \\
\hline & \multicolumn{5}{|c|}{ Proportions of constituents } \\
\hline $7(S)$ & $1 \cdot 0$ & $0 \cdot 14$ & $\mathbf{1 . 5}$ & $\mathbf{0} \cdot \mathbf{3 9}$ & $1.5 \dagger$ \\
\hline CL $11(R)$ & $1 \cdot 0$ & $0 \cdot 23$ & $0 \cdot 42$ & $0 \cdot 39$ & $2 \cdot 5$ \\
\hline $6(S)$ & $1 \cdot 0$ & $0 \cdot 17$ & $1 \cdot 1$ & $0 \cdot 39$ & $1 \cdot 7$ \\
\hline $4(R)$ & $1 \cdot 0$ & $0 \cdot 11$ & $0 \cdot 42$ & $0 \cdot 35$ & $1 \cdot 7$ \\
\hline
\end{tabular}

During hydrolysis of cell walls in $2 \mathrm{~N}-\mathrm{HCl}$ at $100^{\circ}$ for the determination of sugars it was noted that the hydrolysate turned pink during the heating period in the case of smooth walls but remained colourless in the case of rough walls. This finding was consistent with all samples of smooth walls. The soluble colour was quite stable, and disappeared upon neutralization. Its absorption spectrum showed a peak at $510 \mathrm{~m} \mu$. A similar but very slightly different spectrum was reproduced with mixtures of tryptophan or indole with mannose, galactose, glucose or rhamnose heated in $2 \mathrm{~N}-\mathrm{HCl}$. This colour reaction of smooth walls was probably due to the interaction of tryptophan or cysteine with a sugar (probably rhamnose or abequose, which are present in smooth walls but not in rough walls) both of which were solubilized from the walls during the hydrolysis. Such colour reactions obtained by mixture of amino acids and sugars are described by Dische (1955). The colour was not obtainable with whole bacteria.

Chromatography of acid hydrolysates of smooth cell walls revealed six spots, identified by the movement of known sugars as hexosamine, galactose, glucose, mannose, rhamnose and abequose. In rough hydrolysates the two chromatographically fast moving sugar components abequose and rhamnose were completely absent. This was borne out in quantitative analyses for the various sugars (Table 2), which indicated a complete loss of abequose, a great decrease in rhamnose and a significant decrease in mannose content. Kröger et al. (1959) reported absence of mannose, rhamnose and abequose from lipopolysaccharide extracted from rough cell walls of Salmonella paratyphi B. The hexosamine values of smooth and rough cells were remarkably close. While glucose was not determined specifically it was also decreased in content since when equal weights of rough and smooth walls were 
hydrolysed, three to four times as much of the rough hydrolysate had to be applied to the paper to obtain spots of the same intensity at the glucose-galactose region when sprayed with the developing reagent.

The presence of sialic acid was demonstrated in Gram-negative organisms by Aaronson \& Lessie (1960) and in Escherichia coli by DeWitt \& Zell (1961). Its presence was sought in mild acid $\left(0 \cdot 1 \mathrm{~N}-\mathrm{H}_{2} \mathrm{SO}_{4}\right)$ hydrolysates of cell walls by the thiobarbituric acid method of Warren (1959) which measures 2-keto-3-deoxy sugar acids. When sialic acid is present this procedure should give a red-orange chromophore which absorbs sharply at $550 \mathrm{~m} \mu$. The rough cell walls yielded this peak, but a sample of smooth cell walls of equivalent weight yielded a very large peak which,

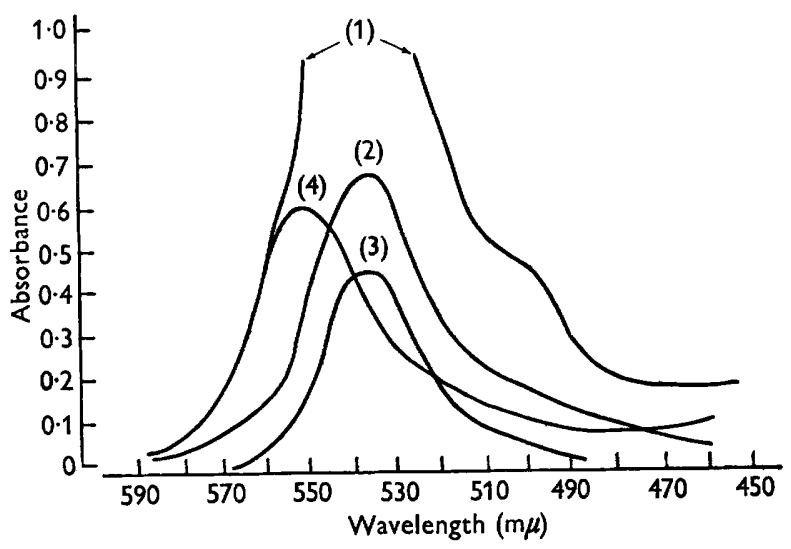

Fig. 1. Absorption spectra of the chromophores, produced in the thiobarbituric acid reaction of Warren and extracted into cyclohexanone, of equal weights of the cell walls of (1) strain 7, smooth undiluted; (2) strain 7 , smooth, diluted; (3) pure abequose; (4) strain CL 11, rough.

when diluted, absorbed maximally at $634 \mathrm{~m} \mu$ (see Fig. 1). This absorption, as can be seen, is characteristic of pure abequose, and the abequose analyses were made by utilizing this absorption peak. Thus it appeared that the abequose present in smooth cell walls masked, by virtue of its overlapping peak, the presence of 'sialic acid'. To determine the presence of 'sialic acid' in the presence of abequose in the smooth walls the chromatographic technique of Aaronson \& Lessie (1960) was used. Paper chromatography of the chromophores, obtained by Warren's procedure, in $10 \%$ $(\mathrm{v} / \mathrm{v})$ ethanol in water as solvent yielded a pink fluorescent spot moving at the solvent front which is characteristic of sialic acid. This pink spot was found in chromatograms from cell walls and whole cells of both rough and smooth strains. In addition there was a stationary white fluorescent spot remaining at the origin in the smooth wall preparations and all four whole cell preparations. This stationary spot was reproduced with pure abequose and deoxyribose. Since the cell walls lacked deoxyribose as determined by Burton's technique it is most likely that the stationary chromophore in smooth cell walls represented abequose. Thus both smooth and rough walls contained 'sialic acid'. The quantitative estimation was made by using the extinction coefficients as determined by Warren. The values for 'sialic acid' content in the rough strains (Table 3) were straightforward since there 
was no masking by the abequose chromophore. The values for the smooth strain were calculated by using Warren's formulae for the determination of sialic acid in the presence of the deoxyribose chromophore which has the same absorption spectrum as the abequose chromophore: hence they may not be as accurate. Allowing for lack of precision of the method in this case it is not likely that there are significant or consistent differences between the 'sialic acid' contents of smooth and rough cell walls.

Table 3. Saccharide content of cell walls of Salmonella typhimurium

\begin{tabular}{|c|c|c|c|c|c|}
\hline \multirow[t]{2}{*}{ Component } & \multirow[t]{2}{*}{ Expressed as: } & \multicolumn{4}{|c|}{$\begin{array}{c}\% \text { dry wt. of preparation. } \\
\text { Strains }\end{array}$} \\
\hline & & $7(S)$ & CL $11(R)$ & $6(S)$ & $4(\mathrm{R})$ \\
\hline $\begin{array}{l}\text { Reducing substance* } \\
\text { (anthrone) }\end{array}$ & Glucose & $15 \cdot 6$ & $3 \cdot 8$ & $10 \cdot 7$ & $4 \cdot 2$ \\
\hline $\begin{array}{l}\text { Hexosamine } \\
\text { (EIson-Morgan) }\end{array}$ & Glucosamine & $4 \cdot 1$ & $3 \cdot 5$ & $3 \cdot 8$ & $3 \cdot 5$ \\
\hline $\begin{array}{l}\text { Pentose } \\
\quad \text { (cysteine }+\mathrm{H}_{2} \mathrm{SO}_{4} \text { ) }\end{array}$ & Rhamnose & $4 \cdot 7$ & $0 \cdot 7$ & $4 \cdot 5$ & $0 \cdot 4$ \\
\hline $\begin{array}{l}\text { Mannose } \\
\text { (cysteine }+\mathrm{H}_{2} \mathrm{SO}_{4} \text { ) }\end{array}$ & Mannose & $4 \cdot 6$ & $1 \cdot 3$ & 4.5 & $1 \cdot 9$ \\
\hline $\begin{array}{l}\text { Heptose } \\
\text { (cysteine }+\mathrm{H}_{2} \mathrm{SO}_{4} \text { ) }\end{array}$ & Heptose & + & + & + & $+\dagger$ \\
\hline $\begin{array}{l}\text { Dideoxy sugar } \\
\text { (thiobarbituric acid) }\end{array}$ & Abequose & $2 \cdot 04$ & 0 & $2 \cdot 6$ & $\mathbf{0}$ \\
\hline $\begin{array}{l}\text { 'Sialic acid' or } \\
\text { 2-keto-3 deoxyocto- } \\
\text { nate (thiobarbituric } \\
\text { acid) }\end{array}$ & $\begin{array}{l}N \text {-acetyl- } \\
\text { neuraminic } \\
\text { acid }\end{array}$ & $1 \cdot 0$ & $1 \cdot 4$ & $0 \cdot 6$ & $2 \cdot 0$ \\
\hline
\end{tabular}

We had assumed that this compound was sialic acid because it was easily removed from the cell wall by mild acid hydrolysis, because of the extinction at $550 \mathrm{~m} \mu$ by its chromophore and by the mobility of the chromophore in chromatography. However, the identification of this component as sialic acid was cast into doubt by the recent finding of Osborne (1963) who has described the presence of 2-keto-3-deoxyoctonate (KDO) in the polysaccharide of an UDP-galactose-4-epimereaseless mutant of Salmonella typhimurium which has a polysaccharide consisting of glucose-heptose-phosphate chains. Osborne showed that compound yielded a chromophore in Warren's reaction with an absorption peak at $549 \mathrm{~m} \mu$, and it seems very likely that KDO is responsible for the characteristic chromophore which we presumed to be due to sialic acid. Further evidence for the presence of KDO is the fact that according to Osborne (1963) it yields an absorption peak in the cysteine + $\mathrm{H}_{2} \mathrm{SO}_{4}$ reaction at $390 \mathrm{~m} \mu$. Such a peak is present in rough cell walls (see Fig. 2) although its presence in the smooth walls is masked by the very large peak due to rhamnose. The final identification of this 2-keto-3-deoxy compound will have to be resolved by its isolation from larger amounts of cell walls than were available for this study.

The spectra of the cell walls in the delayed cysteine $+\mathrm{H}_{2} \mathrm{SO}_{4}$ reaction (Dische, 1955) are illustrated in Fig. 2. Note the great similarity of the absorption spectra of 
the two smooth strains and the two rough strains in spite of the fact that each pair was of separate origin. According to Dische (1955) the peak at $600 \mathrm{~m} \mu$ represents galactose, glucose and mannose; galactose yields an additional peak at $390 \mathrm{~m} \mu$ and glucose at $400-410 \mathrm{~m} \mu$; methylpentoses yield a peak with a maximum at $400 \mathrm{~m} \mu$. These findings are consistent with the chromatographic analysis. The peak absorbing maximally at about $430-450 \mathrm{~m} \mu$, only by the smooth cell walls, remains to be explained. The absorption spectrum of the cell walls in cysteine $+\mathrm{H}_{2} \mathrm{SO}_{4}$ reaction revealed an absorption peak which increased its intensity with time in the region of

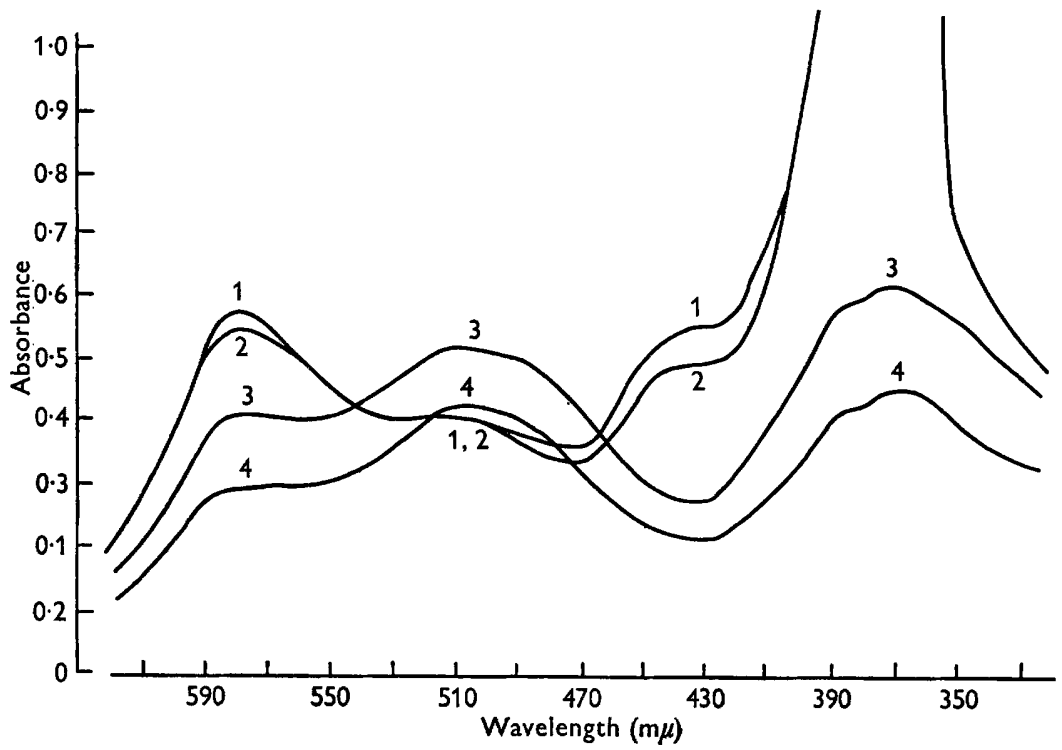

Fig. 2. The absorption spectrum of cell walls produced in the cysteine $+\mathrm{H}_{2} \mathrm{SO}_{4}$ reaction, after $24 \mathrm{hr}$ at room temperature, of (1) strain 7, smooth, 1.34 mg.; (2) strain 6, smooth, $1.32 \mathrm{mg}$.; (3) strain CL 11, rough, $2.08 \mathrm{mg}$.; and (4) strain 4, rough, $2 \cdot 24 \mathrm{mg}$.

$510 \mathrm{~m} \mu$ which, according to Dische (1955), is indicative of heptose. This peak, which reached its greatest intensity at $8 \mathrm{hr}$, was present in both the smooth and the rough cell walls (see Fig. 3). The change in this absorption peak was measured with time for different quantities of cell walls. The relative increase with time was similar for both types of wall indicating a reaction of the same kind of sugar. Table 4 also shows that when calculated on the basis of absorption/mg. cell wall material, there was slightly less heptose in rough walls than in smooth walls. Kaufmann et al. (1961) found heptose in the extracted lipopolysaccharide of both smooth and rough forms. Kröger et al. (1959), who studied the composition of lipopolysaccharide from cell walls of smooth and rough Salmonella paratyphi $\mathbf{B}$, found heptose in both. The analysis for heptose is not as reliable as those developed for other sugars and we would reserve judgement on these results until more precise methods are available.

Chromatography of acid and alkaline hydrolysates of cell walls for their amino acid composition revealed a full complement of amino acids, about 15-18, including diaminopimelic acid, which did not differ qualitatively between smooth and rough strains. 


\section{Susceptibility of cell walls to 'lysis'}

The marked differences in composition between smooth and rough cell walls led us to study their susceptibility to 'lytic' disruption. This phenomemon was studied by following changes in extinction of suspensions. Shafa \& Salton (1960) reported on the disruption of Gram-negative cell walls by sodium lauryl sulphate. This was tested in the present investigation by suspending bacteria in two concentrations of the detergent and observing changes in extinction with time. The results

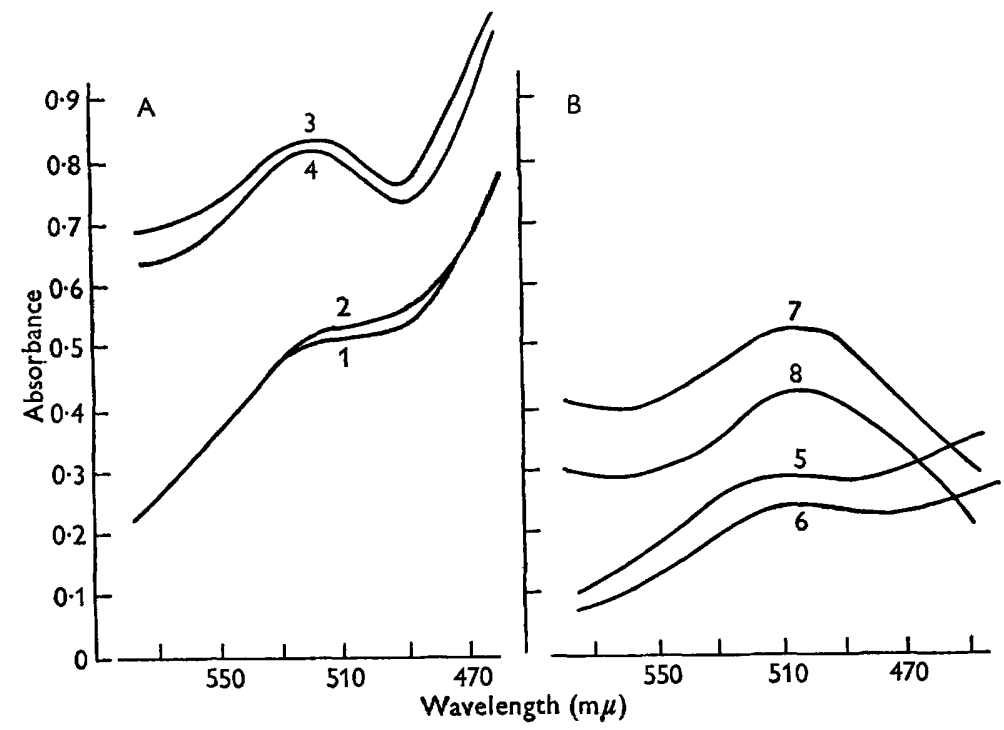

Fig. 3. Changes in absorption spectra, with time, of cell walls in the cysteine $+\mathrm{H}_{2} \mathrm{SO}_{4}$ reaction: A, smooth strains, B, rough strains. (1) Strain 6, smooth, $2.68 \mathrm{mg}$., at $30 \mathrm{~min}$. and (3) the same at $8 \mathrm{hr}$; (2) strain 6, smooth, $2.64 \mathrm{mg}$. at $30 \mathrm{~min}$. and (4) the same at $8 \mathrm{hr}$; (5) strain 4 , rough $2.24 \mathrm{mg}$. at $30 \mathrm{~min}$. and (7) the same at $8 \mathrm{hr}$; (6) strain $\mathrm{CL} \mathrm{11,} \mathrm{rough,}$ 2.08 $\mathrm{mg}$. at $30 \mathrm{~min}$. and (8) the same at $8 \mathrm{hr}$.

Table 4. Spectral behaviour at $510 \mathrm{~m} \mu$ in the cysteine $+\mathrm{H}_{2} \mathrm{SO}_{4}$ reaction of smooth and rough cell walls of Salmonella typhimurium

\begin{tabular}{|c|c|c|c|c|c|c|c|}
\hline \multirow{2}{*}{$\begin{array}{l}\text { S. typhimurium } \\
\text { strain no. }\end{array}$} & \multirow{2}{*}{$\begin{array}{l}\text { Weight of } \\
\text { cell walls } \\
\text { (mg.) }\end{array}$} & \multicolumn{2}{|c|}{$\begin{array}{c}\text { Extinction } \\
(510 \mathrm{~m} \mu)\end{array}$} & \multirow{2}{*}{$\begin{array}{l}\% \text { Increase } \\
\text { extinction } \\
(510 \mathrm{~m} \mu)\end{array}$} & \multicolumn{2}{|c|}{$\begin{array}{l}\text { Extinction/ } \\
\text { mg. cell wall }\end{array}$} & \multirow[b]{2}{*}{ Mean } \\
\hline & & $30 \mathrm{~min}$. & $8 \mathrm{hr}$ & & $30 \mathrm{~min}$. & $8 \mathrm{hr}$ & \\
\hline \multirow[t]{3}{*}{$7(S)$} & $2 \cdot 68$ & 0.52 & $0 \cdot 82$ & 158 & $0 \cdot 19$ & $0.31)$ & \multirow{3}{*}{$0 \cdot 29$} \\
\hline & $1 \cdot 34$ & $0 \cdot 18$ & $0 \cdot 38$ & 228 & $0 \cdot 13$ & 0.28 & \\
\hline & $0 \cdot 67$ & 0.09 & $0 \cdot 19$ & 211 & $0 \cdot 13$ & 0.28 & \\
\hline \multirow[t]{3}{*}{$6(\mathrm{~S})$} & $2 \cdot 64$ & $0 \cdot 52$ & $0 \cdot 81$ & 156 & 0.20 & $0.31)$ & \multirow{3}{*}{$0 \cdot 29$} \\
\hline & $1 \cdot 32$ & $0 \cdot 19$ & $0 \cdot 38$ & 200 & $0 \cdot 14$ & 0.29 & \\
\hline & $0 \cdot 66$ & 0.09 & $0 \cdot 18$ & 200 & $0 \cdot 14$ & $0 \cdot 27$ & \\
\hline \multirow[t]{3}{*}{ CL 11(R) } & $4 \cdot 16$ & $0 \cdot 84$ & $\mathbf{1} \cdot \mathbf{2 0}$ & 143 & $0 \cdot 20$ & 0.29 & \multirow{3}{*}{$0 \cdot 26$} \\
\hline & $2 \cdot 08$ & $0 \cdot 29$ & 0.50 & 172 & $0 \cdot 14$ & $0 \cdot 24$ & \\
\hline & $1 \cdot 04$ & $0 \cdot 13$ & 0.25 & 192 & $0 \cdot 13$ & 0.24 & \\
\hline \multirow[t]{3}{*}{$4(R)$} & $4 \cdot 48$ & $0 \cdot 63$ & 0.97 & 152 & $0 \cdot 14$ & $0 \cdot 22)$ & \multirow{3}{*}{$0 \cdot 20$} \\
\hline & $2 \cdot 24$ & $0 \cdot 23$ & $0 \cdot 41$ & 178 & $0 \cdot 10$ & $0.18\}$ & \\
\hline & $1 \cdot 12$ & $0 \cdot 10$ & $0 \cdot 20$ & 200 & 0.09 & $0 \cdot 19$ & \\
\hline
\end{tabular}


(Fig. 4) indicated a consistently greater susceptibility of smooth cell walls in contrast to rough cell walls with both strains. In $0 \cdot 1 \%$ detergent the smooth strain (7) showed a $60 \%$ decrease in extinction while its derived rough variant (CL 11) lost only $43 \%$. The situation was similar between the smooth strain 6 , which lost $54 \%$ and its derived rough form, strain 4 , which lost $30 \%$.
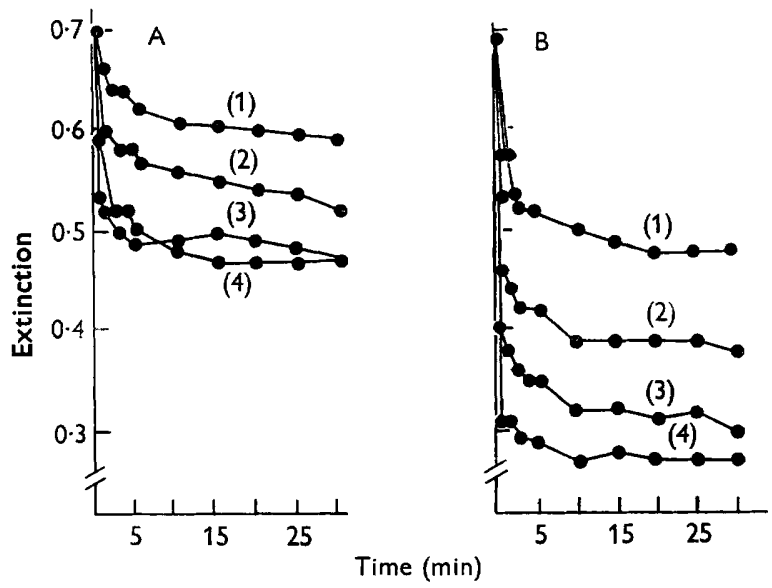

Fig. 4. Changes in extinction of cell walls in two concentrations of sodium lauryl sulphate: $A, 0 \cdot 05 \%(w / v)$ and $B, 0 \cdot 10 \%(w / v)$ of cell walls of (1) strain 4, rough; (2) strain CL 11 , rough; (3) strain 6 , smooth; (4) strain 7 , smooth.

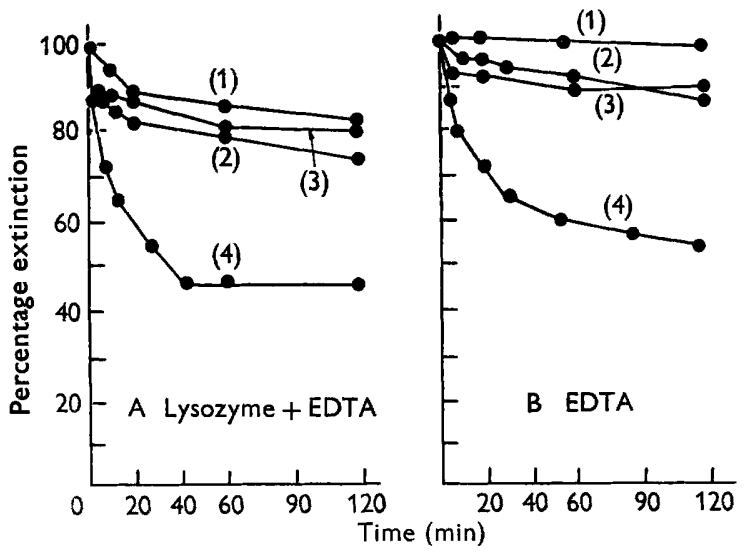

Fig. 5. Changes in extinction of cells of strain $7(\mathrm{~S})$ grown in (1) lactate defined medium of Fraser; (2) glycerol defined medium of Fraser; (3) on brain-heart infusion agar; and in (4) Trypticase sea-water broth and subsequently exposed to $10 \mu \mathrm{g}$. lysozyme $/ \mathrm{ml}$. $+0.32 \mathrm{mg}$. EDTA $/ \mathrm{ml}$. in A, or to $0.32 \mathrm{mg}$. EDTA $/ \mathrm{ml}$. in B. Expressed as percentage of buffer control.

The attack on the mucopeptide layer of Escherichia coli by lysozyme was shown by Repaske (1956), who added EDTA in order to achieve lysis of Gram-negative organisms by lysozyme. We wished to test the susceptibility of the mucopeptide layer of the two types of Salmonella organisms. Using Repaske's technique on 
bacteria grown for $24 \mathrm{hr}$ in Fraser media (Fraser \& Jerrell, 1953) resulted in very little lysis of any of the four strains by EDTA or EDTA + lysozyme (see Fig. 5). We are unable to explain this refractory state; Repaske has recorded such an effect with aged organisms. It was suggested (Dr D. B. Pratt, personal communication) that

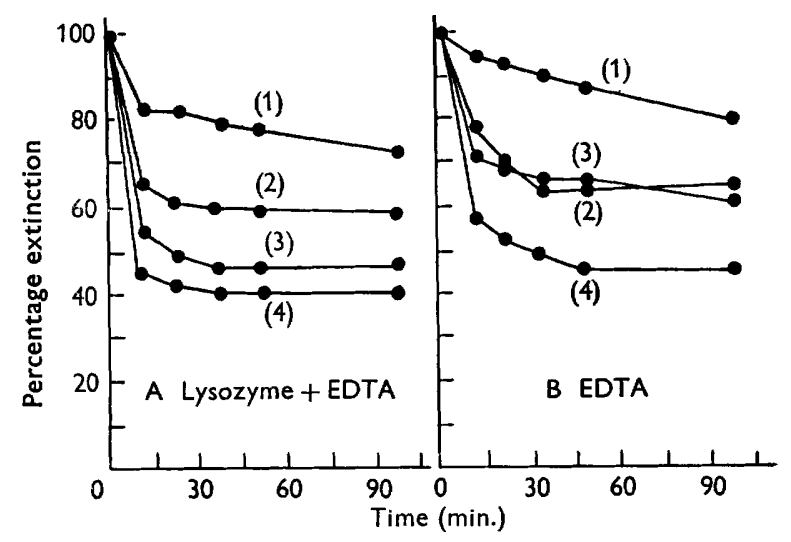

Fig. 6. Changes in extinction of bacteria grown in Trypticase-sea water medium and subsequently exposed to $10 \mu \mathrm{g}$. lysozyme $/ \mathrm{ml}$. $+0.32 \mathrm{mg}$. EDTA $/ \mathrm{ml}$. in A, or to $0.32 \mathrm{mg}$. EDTA $/ \mathrm{ml}$. in B. Expressed as percentage of buffer control. (1) Strain 7, smooth; (2) strain 6, smooth; (3) strain cL 11, rough; (4) strain 4, rough.

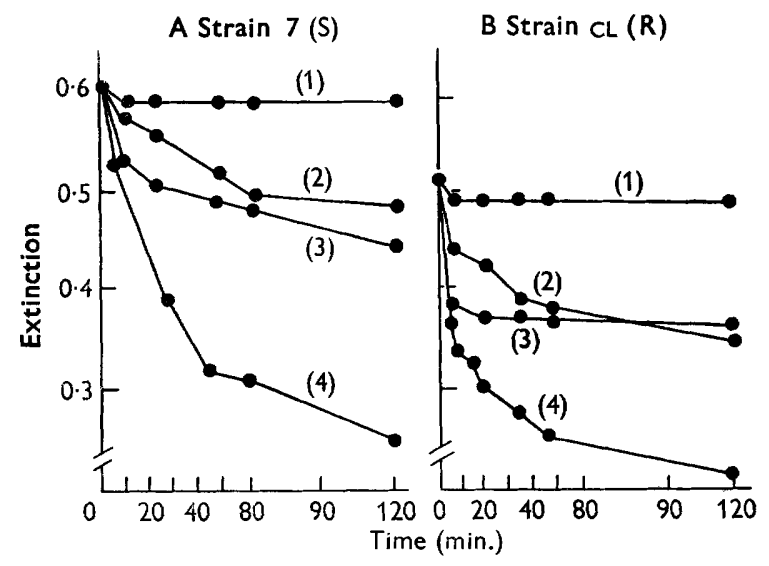

Fig. 7. Changes in extinction of cell walls of a smooth strain $\boldsymbol{\gamma ( S )}$ in $A$, and a rough strain CL $11(\mathbf{R})$ in $B$, prepared from cultures grown in brain heart infusion broth in: (1) buffer; (2) $10 \mu \mathrm{g}$. lysozyme $/ \mathrm{ml}$.; (3) $0.32 \mathrm{mg}$. EDTA $/ \mathrm{ml}$; ; and (4) in the combination of lysozyme and EDTA.

increasing the internal osmotic pressure of the bacteria by growing them in a medium of high salt concentration might yield organisms more susceptible to massive visible lysis; this proved to be the case with our strains (see Fig. 5). Upon growth in Trypticase sea-water, overnight and subsequent washing, the bacteria were rapidly and consistently lysed not only by the EDTA +lysozyme but also by EDTA alone (see Fig. 6). A comparison of smooth and rough bacteria grown in Trypticase sea-water revealed striking differences in the susceptibility of the 
bacteria to lysis (Fig. 6). For both strains the rough variants were more susceptible to lysis than the smooth forms. However, the degree of lysis achieved by EDTA was not greatly enhanced by the presence of lysozyme. It is possible that the effect found here was not solely due to an attack on the mucopeptide layer. We also studied the effect on the cell walls rather than on whole bacteria. A typical experiment is shown in Fig. 7. In both cases, i.e. smooth and rough bacteria, EDTA alone or lysozyme alone effected some decrease in extinction. However, the EDTA+ lysozyme definitely enhanced the degree of lysis. A comparison of smooth and rough cell walls (Fig. 8) indicated a greater susceptibility of rough walls to lysis by EDTA + lysozyme than smooth walls and the final OD in the case of rough cell walls was always lower than its smooth parent strain (strain 7 against CL 11 and strain 6 against 4). The effect with EDTA alone was not correlated with the EDTA+ lysozyme effect and was of much lower magnitude.

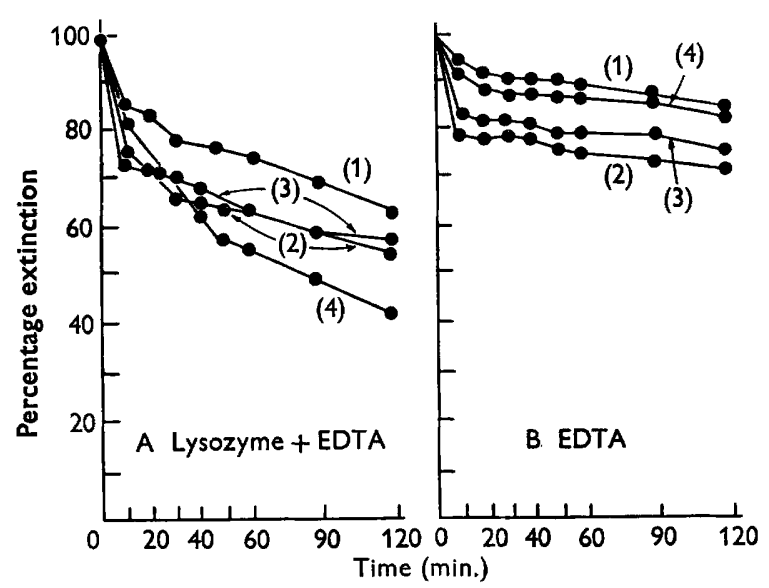

Fig. 8. Changes in extinction of cell walls of smooth and rough strains prepared from cultures grown in brain heart infusion broth in $10 \mu \mathrm{g}$. lysozyme $/ \mathrm{ml} .+0 \cdot 32 \mathrm{mg}$. EDTA/ml. in $A$, or in $0.32 \mathrm{mg}$. EDTA/ml. in B. (1) Strain 7, smooth; (2) strain 6, smooth; (3) strain CL 11, rough; (4) strain 4, rough. Expressed as percentage of buffer control.

\section{DISCUSSION}

The mutation from smooth to rough in two strains of Salmonella typhimurium resulted in synthesis of a cell wall containing less carbohydrate. This appears to be the only significant change. The similarity of the nitrogen, phosphorus and hexosamine values would indicate little or no change in the protein, phospholipid or mucopeptide components. This is further reflected in the lack of significant changes found in amino acid composition. The changes in carbohydrate composition are similar to those found with extracted lipopolysaccharide of smooth and rough strains by Kaufmann et al. (1961), i.e. loss of rhamnose and abequose. In addition, rough cell walls are generally lower in content of all sugars. This would also indicate that the extractable polysaccharide in the form of lipopolysaccharide represents an extraction of the entire sugar moiety of the cell wall with the exception of hexosamine which is also part of the inner rigid layer (Weidel, Frank \& Martin, 1960) of Escherichia coli. Since no significant change was found in lipid content and a con- 
sistent loss in sugars occurred in the $\mathbf{S} \rightarrow \mathbf{R}$ change, the loss in toxicity of the whole organisms and cell walls of rough variants (see Table 1) can be most reasonably ascribed to the polysaccharide moiety. This finding tends to support Ribi's contention (Ribi, Haskins, Landy \& Milner, 1961) that the polysaccharide moiety is responsible for toxicity rather than the lipid moiety as postulated by Westphal (1960).

All of the values determined for the composition of the cell walls had to be based on dry weight, i.e. as percentages or related to nitrogen, i.e. as ratios. It might have been expected that the lower carbohydrate content of rough cell walls would be compensated for by an increase in some or all of the other components, but this was not the case. There was no significant increase in percentage dry weight of any component measured, to compensate for the loss. This might mean that the methods are not of great enough precision to account for all of the components quantitatively, or that all components were not accounted for. The density of the rough cell walls did not differ appreciably from the smooth cell walls, indicating that a large imbalance of components contributing to different densities did not exist.

The mucopeptide layer which is innermost according to Weidel et al. (1960), appears from our results to be essentially the same for the smooth and the rough forms; although we did not determine muramic acid specifically the hexosamine values were very close. The most reasonable hypothesis to account for their differences in susceptibility to lysis by EDTA + lysozyme would hold that they differ primarily in the accessibility of the mucopeptide layer to the lysozyme activity. Thus the higher polysaccharide content of smooth walls might act as a cover, protective against lysozyme. Whether this protective effect is due to a steric hindrance of the enzyme, keeping it away from its substrate in the case of smooth walls or change in the surface charge, enabling closer lysozyme penetration in the case of rough walls remains to be elucidated. Rough cells appear to be more hydrophobic (White, 1929) than smooth bacteria, as is apparent by their spontaneous agglutination in saline, and their surface charge can be altered, as shown by electrophoretic mobility of rough and smooth Brucella organisms (Stearns \& Roepke, 1941). It was noted in our experiments that lysozyme without EDTA agglutinated rough bacteria but had no effect on smooth bacteria. This observation would suggest to us a greater affinity of the enzyme for the rough surface. The striking effect of EDTA alone on Salmonella typhimurium grown in sea-water medium might be explained by its chelating effect in removing an ion such as $\mathrm{Mg}^{2+}$ which has been shown to protect marine bacteria from osmotic lysis (Pratt, Bielling \& Tyler, 1959). This effect, while of lesser magnitude in the case of cell walls and preparations of whole bacteria is nevertheless present. It is admitted that lysis as observed in the present experiments represented only decrease of extinction and that other effects on extinction such as the ionic effect shown by Avi-Dor, Kuczynski, Schatzberg \& Mager (1956), might be responsible. The release of components in a soluble form from the organism or cell wall would have to be shown, to use the term lysis unequivocally.

This disclaimer of the term lysis also applies to the effects of sodium lauryl sulphate which unexpectedly had a greater effect on smooth cell walls than on rough cell walls. Its mechanism does not appear to be due to a disruption of protein structure since Shafa \& Salton (1960) showed that in disaggregating cell walls it did not release sulphydryl (thiol) groups. The greater susceptibility of smooth cell wall 
suspensions to show extinction changes may be due either to a greater susceptibility of the protein-lipid bonds than in rough cell walls or to the presence of a larger amount of substance which is susceptible to loss than one finds in the rough cell walls. Since the only difference between the two is carbohydrate content rather than protein, carbohydrate might be the substance whose presence contributes to a greater susceptibility to detergent disruption. This can only be determined by an analysis of the supernatant fluid from cell walls disrupted by this means. Another possible explanation would be that a different arrangement of the protein, lipid and polysaccharide moieties exists in smooth walls which is more easily disrupted by the detergent action than the arrangement in rough walls.

Davies (1957) postulated that mutation from smooth to rough in Shigella dysenteriae was not due to an uncovering of rough antigen due to loss of the smooth antigen. He felt that it was due to the synthesis of a different polysaccharide. which shared some, but not all, of the monosaccharide moieties of the smooth substance. This hypothesis was supported by his work with variation in Pasteurella pseudotuberculosis (Davies, 1958) and by the study of Salmonella by Kaufmann et al. (1961). The latter workers showed that rough mutants were minus variants of their respective smooth forms only in regard to certain sugars. Our work supports this idea of rough forms being minus variants solely in the polysaccharide moiety since other components of the cell wall were unaffected by the mutation.

The authors acknowledge their indebtedness to the following persons: Dr Ellen Simon (University of Wisconsin) for strains of Salmonella typhimurium; Dr $\mathrm{O}$. Westphal (Wander-Forschung Institute, Freiburg-Zähringen, Germany) for a sample of pure abequose; Mr J. W. Carlisle (University of Florida) for the electron microscopy; Mr Max Risinger for expert technical assistance.

This study was supported in part by a research grant, AI-01663 from the National Institute of Allergy and Infectious Diseases, U.S. Public Health Service.

\section{REFERENCES}

Aaronson, S. \& Lessie, T. (1960). Nonulosaminic acid (sialic acid) in protists. Nature, Lond. 186, 719.

Avi-Dor, Y., Kuczynski, M., Schatzberg, G. \& Mager, J. (1956). Turbidity changes in bacterial suspensions: kinetics and relation to metabolic state. J.gen. Microbiol. 14, 76.

Burton, K. (1956). A study of the conditions and mechanism of the diphenylamine reaction for the colorimetric estimation of deoxyribonucleic acid. Biochem. J. 62, 315.

Carex, W. F. \& Baron, L. S. (1959). Comparative immunologic studies of cell structures isolated from Salmonella typhosa. J. Immunol. 83, 517.

DAvies, D. A. L. (1957). Isolation of a 'rough' somatic antigen from Shigella dysenteriae. Biochem. biophys. Acta, 26, 151.

Davies, D. A. L. (1958). The smooth and rough antigens of Pasteurella pseudotuberculosis. J. gen. Microbiol. 18, 118.

DE WITT, C. W. \& ZeLL, E. A. (1961). Sialic acids in Escherichia coli. II. Their presence on the cell wall surface and their relationship to $K$ antigen. $J$. Bact. 32, 849.

Dische, Z. (1955). New colour reactions for the determination of sugars in polysaccharides. Meth. Biochem. Anal. 2, 313.

Dische, Z. \& Shetrles, L. B. (1948). A specific colour reaction of methylpentoses and a spectrophotometric micromethod for their determination. J. biol. Chem. 165, 595.

Edwards, P. R. \& Ewing, W. H. (1962). Identification of Enterobacteriaceae. Minneapolis, Minnesota: Burgess Publishing Co. 
Fiske, C. \& SubbaRow, 'T. (1925). The colorimetric determination of phosphorus. J. biol. Chem. 66, 375.

Fraser, D. \& Jerrel, E. A. (1953). The amino acid composition of $T_{3}$ bacteriophage. J. biol. Chem. 205, 291.

Goldberg, L. J., Watkins, H. M. S., Dolmatz, M. S. \& Schlamm, N. A. (1954). Studies on the experimental epidemiology of respiratory infections. J. infect. Dis. 94, 9.

Harrow, B., Borek, E., Mazur, A., Stone, C. C. H. \& Wagreich, H. (1955). Laboratory Manual of Biochemistry, 4th ed. Philadelphia and London: W. B. Saunders Co.

Herzberg, M. (1962). Living organisms as immunizing agents against experimental salmonellosis in mice. I. Virulence of auxotrophic mutants. J. infect. Dis. 111, 192.

Herzberg, M., Green, J. H. \& Boring, J. C. (1960). Composition of cell walls of Salmonella typhimurium. Bact. Proc. p. 169.

KABAт, E. A. \& MAYER, M. M. (1961). Experimental Immunochemistry, 2nd ed. Springfield, Illinois : C. C. Thomas.

Kaufmann, F., Kruger, L., Lüderitz, O. \& Westrphal, O. (1961). Zur Immunchemie der O-Antigene von Enterobacteriaceae. VI. Vergleich der Zuckerbausteine von Polysacchariden aus Salmonella-S-und R-Formen. Z. Bakt. I. Abt. Orig. 182, 57.

Knöger, E., Lüdenitz, O. \& Westphal O. (1959). Zuckerbausteine-Analyse der endotoxischen Lipopolysaccharide aus gramnegativen Bakterien und ihren isolierten Zellwänden. Naturwissenschaften. 13, 428.

Lüderitz, O., Kaufmann, F., Stierlin, H. \& Westphal, O. (1960). Zur Immunchemic der O-Antigene von Enterobacteriaceae. II. Vergleich der Zuckerbausteine von Salmonella S-, R- und T-Formen. Z. Bakt. I. Abt. Orig. 179, 180.

Osborne, M. J. (1963). Studies on the gram-negative cell wall. I. Evidence for the role or 2-keto-3-deoxyoctonate in the lipopolysaccharide of Salmonella typhimurium. Proc. nat. Acad. Sci., Wash. 50, 499.

Partridge, S. M. (1949). Aniline hydrogen phthalate as a spraying reagent for chromatography of sugars. Nature, Lond. 164, 443.

Partridge, S. M. \& Westall, R. (1948). Filter paper partition chromatography of sugars. I. General description and application to the qualitative analysis of sugars in apple juice, egg white and foetal blood of sheep. Biochem. J. 42, 238.

Pratt, D. B., Bielling, M. C. \& Tyler, M. E. (1959). Variation in osmotic fragility of marine bacteria. Bact. Proc. p. 11.

Pratt, D. B. \& Happolo, F. C. (1960). Requirements for indole production by cells and extracts of a marine bacterium. J. Bact. 80, 232.

Ribi, E., Haskins, W. T., Landy, M. \& Milner, K. C. (1961). Symposium on bacterial endotoxins. I. Relationship of chemical composition to biological activity. Bact. Rev. 25, 427.

Repaske, R. (1956). Lysis of gram-negative bacteria by lysozyme. Biochem. biophys. Acta, 22, 189.

Salton, M. R. J. (1953). Studies of the bacterial cell wall. IV. The composition of the cell walls of some Gram positive and Gram negative bacteria. Biochem. biophys. Acta, 10, 512.

Salton, M. R. J. (1960). Surface layers of the bacterial cell. In The Bacteria. Ed. by R. Y. Stanier \& I. C. Gunsalus. New York and London: Academic Press.

Salton, M. R. J. \& Horne, R. W. (1951). Studies of the bacterial cell wall. II. Methods of preparation and some properties of cell walls. Biochem. biophys. Acta, 7, 17 .

Shafa, F. \& Salton, M. R. J. (1960). Disaggregation of bacterial cell walls by anionic detergents. J. gen. Microbiol. 23, 137.

Staub, A. M., Tinelli, R., Lüderitz, O. \& Westrhal, O. (1959). Étude immunochemique sur les Salmonella. V. Role de quelques Sucres, et en particulier des 3-6 didésoxyhexoses, dans la spécificité des antigenes $\mathrm{O}$ du tableau de Kaufmann-White. Annls Inst. Pasteur, Paris, 96, 303.

Stearns, T. W. \& Roepke, M. H. (1941). The effect of dissociation on the electrophoretic mobility of brucella. J. Bact. 42, 745 .

Wardraw, A. C. (1963). The complement dependent bacteriolytic activity of normal human serum. II. Cell wall composition of sensitive and resistant strains. Can. J. Microbiol. 9, 41. 
WARREN, L. (1959). The thiobarbituric acid assay of sialic acids. J. biol. Chem. 234, 1971. Weidel, W., Frank, H. \& Martin, H. H. (1960). The rigid layer of the cell wall of Escherichia coli, strain в. J. gen. Microbiol. 22, 158.

Westphal, O. (1960). Recentes recherches sur la chemie et la biologie des endotoxines des bacteries à Gram negatif. Annls Inst. Pasteur, Paris, 98, 789.

White, P. B. (1929). The Salmonella group. In A System of Bacteriology in Relation to Medicine. London: Her Majesty's Stationery Office.

\section{EXPLANATION OF PLATE}

Electron photomicrographs of cell walls of strains of Salmonella typhimurium, chromium shadowed (17 ${ }^{\circ}$ angle).

Fig. 1. Strain 7, smooth, magnification $\times 6000$.

Fig. 2. Strain CL 11, rough, magnification $\times 12000$

Fig. 3. Strain 6 , smooth, magnification $\times 6000$.

Fig. 4. Strain 4, rough, magnification $\times 12,000$.

Fig. 5. Strain CL 11, magnification $\times 6000$, demonstrating an unbroken cell containing cytoplasmic components amid cell walls. Note that the disk-like inclusions of cell walls differ from the electron-dense cytoplasmic inclusions. 

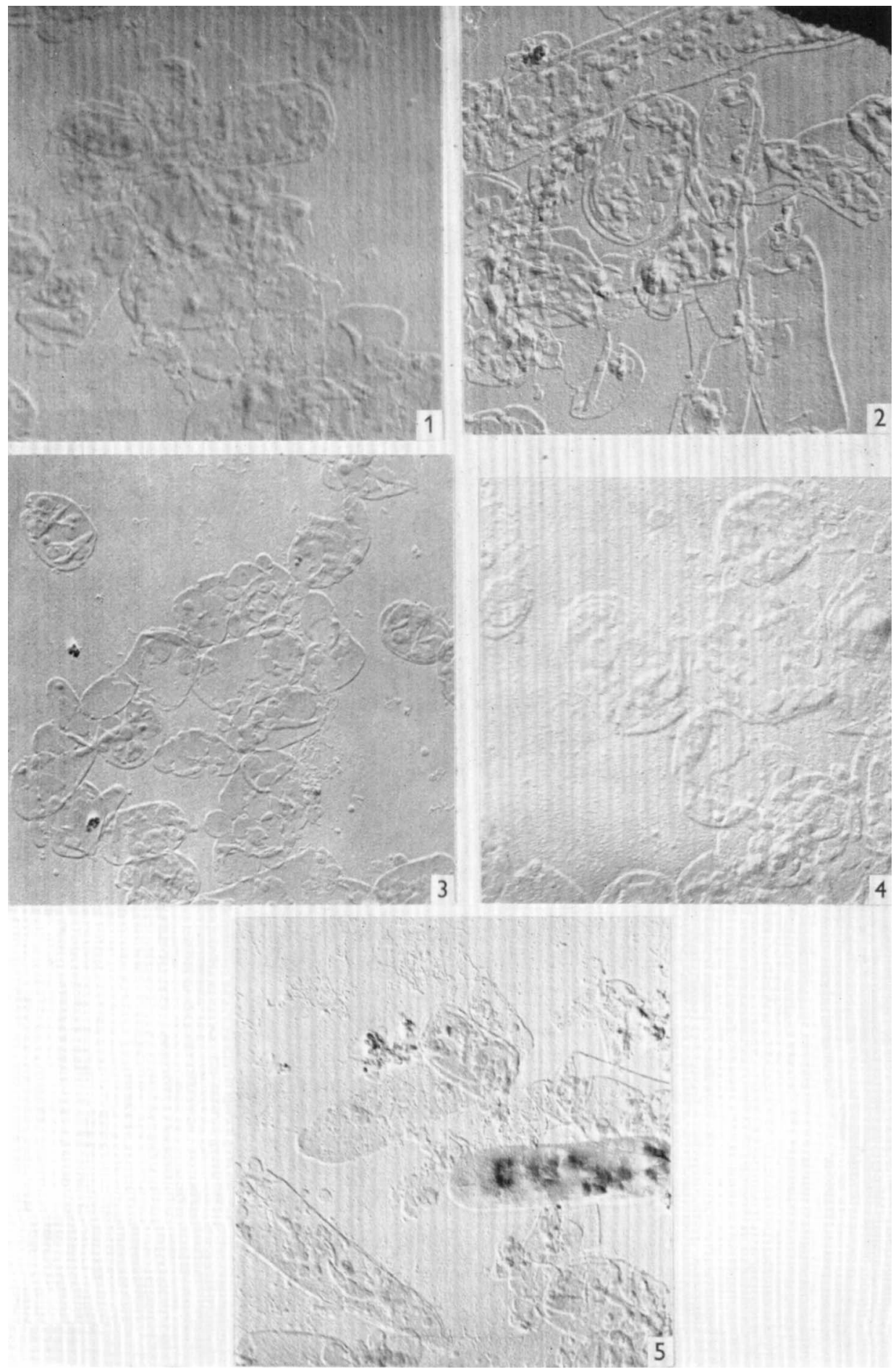

M. HERZBERG AND J. H. GREEN

(Facing p. 436) 